TRANSACTIONS OF THE

ROYAL HISTORICAL SOCIETY

PRESIDENTIAL ADDRESS

By Margot C. Finn

MATERIAL TURNS IN BRITISH HISTORY: IV.

EMPIRE IN INDIA, CANCEL CULTURES AND THE COUNTRY HOUSE

READ 27 NOVEMBER 2020

ABSTRACT. This lecture seeks to historicise the so-called 'cancel culture' associated with the 'culture wars' waged in Britain in c. 2020. Focusing on empire and on the domestic, British impacts of Georgian-era imperial material cultures, it argues that dominant proponents of these 'culture wars' in the public sphere fundamentally distort the British pasts they vociferously claim to preserve and defend. By failing to acknowledge the extent to which eighteenth- and nineteenth-century British men and women themselves contested imperial expansion under the aegis of the East India Company_and decried its impact on British material culture, including iconic stately homes - twenty-first-century exponents of culture wars who rail against the present-day rise of histories of race and empire in the heritage sector themselves erase key layers of British experience. In so doing, they impoverish public understanding of the past.

This is my fourth lecture for the Royal Historical Society on 'Material Turns in British History', exploring how attention to colonial and material cultures can enhance our 
understanding of the British past. It has been composed in what can only be described as historic times. Against a backdrop of environmental calamity and amidst a global epidemiological crisis, historians labour today in the throes of a so-called culture war, in which empire and colonialism are key protagonists. 'Cancel cultures' are conspicuous in the armoury of this cultural conflict. 'Cancel culture refers to the popular practice of withdrawing support for (cancelling) public figures and companies after they have done or said something considered objectionable or offensive,' the Pop Culture Dictionary explains. 'Cancel culture is generally discussed as being performed on social media in the form of group shaming.' ${ }^{1}$ History has come under repeated fire from all political sides and generational cohorts in this heady atmosphere. In tonight's lecture, I trace a few highly visible threads among the rich tapestry of this contemporary conflict and seek, by locating the British country house within histories of imperialism, to situate today's 'culture wars' in both a broader and a longer historical context.

My lecture is in three main parts. I begin with a sweeping, and necessarily schematic, survey of today's soi-disant culture war in Britain, focusing on its dominant timelines and cast of characters and noting the peculiar erasure of the East India Company (EIC) that characterises social media-enabled debates about British imperialism. I turn in the next two sections to the closely entwined histories of the East India Company and the British country house, suggesting that erasure and selective historical amnesia — cancelling, if you will— were woven into the history of the stately home in the Georgian and early Victorian years in ways that pre-figure twentieth- and twenty-first century repressions and re-imaginings of empire in the public and the scholarly imaginations. In my conclusion, I return to our

\footnotetext{
${ }^{1}$ Pop Culture Dictionary: https://www.dictionary.com/e/pop-culture/cancel-culture/ : 'cancel culture'. Similarly, the online Cambridge dictionary defines cancel culture as 'a way of behaving in a society or group, especially on social media, in which it is common to completely reject and stop supporting someone because they have said or done something that offends you': https://dictionary.cambridge.org/dictionary/english/cancelculture. Both sources accessed 9 July 2021.
} 
contemporary culture war, underlining the need to push beyond facile conceptions of the past that 'cancel' or deny earlier generations' participation in robust, contentious debates about the domestic impact of Britain's empire. Not only school and university curriculums, museums, and cultural organisations such as the National Trust, but also commercial venues, the Church of England, the military and representatives of the monarchy are now caught up in the legacies of this contested heritage. ${ }^{2}$ If we are to engage intelligently with these debates, I suggest, it behoves us to acknowledge and understand their extended, conflicted genealogy.

\section{Culture War(s)?}

Do we live in times riven by one or more 'culture wars'? The popular press, some politicians and many Twitter users are convinced that we do. Their conviction resounds from the pages of the Daily Mail, which locates the key battlefields of the culture war in identity politicsmost notably in claims for racial equality that have been brought to the forefront of public consciousness by Black Lives Matter. Reporting in June 2020 that the prime minister had selected Munira Mirza to set up his new race commission, the Mail proclaimed 'No10 "declares war on woke": Boris Johnson "is taking on cultural battles over statues to shore up Tory base"". ${ }^{3}$ As monuments to local worthies and national icons have toppled from (or trembled on) their pedestals, History and History's alleged cancellation have loomed increasingly large in this narrative of cultural Armageddon. September 2020 saw the actor

\footnotetext{
${ }^{2}$ Abundant evidence of the diverse stakeholders caught up in the 'culture wars' can be found in the webpages of Policy Exchange's 'History Matters' project, discussed below. At the time of this lecture's delivery, Policy Exchange had published four 'editions' of material for this project. At the time of finalising this text, nine editions had been published: https://policyexchange.org.uk/history-matters-project/ (accessed 9 July 2021). ${ }^{3}$ Daily Mail, 16 June 2020.
} 
Laurence Fox announce his determination to launch a new political party, in the aftermath of his assertion that pervasive discussions of racism in the media were 'boring'. The Daily Mail's report of Fox's initiative quoted his claim that 'The people of the United Kingdom are tired of being told that we represent the very thing we have, in history, stood together against', noting his objective of 'celebrating Britain's cultural history' in the face of such critiques. $^{4}$

In newspapers, on Twitter, and within both houses of Parliament, 'culture war' and 'cancel culture' are now bandied about by Conservative commentators as signifiers of all that is wrong with a section of the public they identify as a cacophonous minority opposed to the 'common sense' traditionalism of a silent majority. The revival of large-scale anti-racism protest in Britain in the aftermath of the killing of George Floyd on 25 May 2020 has both accelerated this conflict and focused it increasingly on histories of empire, race and nation. In July 2020, Conservative MP John Hayes launched the 'Common Sense' group of MPs and peers to 'deliver on the Conservative pledge to control immigration and so keep faith with blue collar Tory voters'. ${ }^{5}$ By September, The Times was reporting that members of this new assemblage had joined forces with the European Research Group to refuse 'unconscious bias training intended to tackle racism in the Commons, accusing parliamentary authorities of "pandering to the woke agenda"... "I would rather gouge my eyes out with a blunt stick than sit through that Marxist, snake oil crap," said one. ${ }^{6}$ As Ben Bradley—newly elected Conservative MP for Mansfield, self-professed 'first blue brick in the red wall' and

\footnotetext{
4 'Some REAL opposition? Laurence Fox to launch new political party to fight "culture wars" with $£ 5$ million from former Tory donors - as Nigel Farage threatens to launch his own anti-lockdown party' (Daily Mail, 27 September 2020). See similarly 'Megxit? It's Brexit all over again! Just when we thought Britain was healing, a new cultural war is raging - but despite hysterical claims, it's NOT to do with racism, insists former equalities minister TREVOR PHILLIPS', Daily Mail, 17 January 2020.

${ }^{5}$ Sir John Hayes, MP, 'We need to stop misplacing common sense on immigration for bigotry, blasts Sir John Hayes', Express, 5 July 2020.

${ }^{6}$ Esther Webber and Eleni Courea, 'Dozens of Tory MPs set to Refuse Unconscious Bias Training', The Times, 21 September 2020.
} 
unconscious bias training refusenik — tweeted in October, '\#CriticalRaceTheory and the \#BLM organisation... are not an innocent anti racism campaign, it's political ideology and should be treated as such!?

More sober and sustained is the 'History Matters' campaign launched by the centreright thinktank, Policy Exchange, in June. Led by the former chair of the Equality and Human Rights Commission, Trevor Phillips, this project is guided by a panel of eleven 'historians, public figures and people interested in history'. 'We all want to find ways to improve the life opportunities and outcomes for people from BAME backgrounds', Phillips wrote in explaining the group's rationale. 'But what concerns me about the current moment is the rapid and unthinking way in which large swathes of our public heritage is [sic] being effectively re-written, or erased entirely - much of it seemingly without much proper debate or forethought. ${ }^{8}$ In both its visual iconography and its straplines, 'History Matters' reflects wider claims that historians - like turkeys voting for Christmas - are intent to cancel History. Led emblematically by Richard Lionheart, its advocates underline 'public concern for the rewriting of history', assert that 'Two thirds of people say judging our past with today's values is mistaken', allege 'Rock bottom support for removing historical statues, including Churchill' and have issued a 'call for evidence as history becomes focus of culture war'. 9

These sentiments have travelled rapidly along the corridors of power, with important ramifications for History in schools, universities and cultural organisations. In September, Oliver Dowden, the Secretary of State for Digital, Culture, Media and Sport, sent twenty-six

\footnotetext{
7 @BBradley_Mans (21 October 2020).

${ }^{8}$ https://policyexchange.org.uk/press-release/policy-exchange-launches-new-history-project/ (accessed 12 November 2020). The choice of 'History Matters' as the rubric for this initiative may strike historians with a longer-term engagement with Black history as ironic: Professor Hakim Adi of the University Chichester established a 'History Matters' coalition in 2014 with quite different assumptions and goals: https://www.younghistoriansproject.org/single-post/2019/03/15/Life-and-times-of-Britains-first-black-Historyprofessor-Hakim-Adi-Part-II.

${ }^{9}$ https://policyexchange.org.uk/press-release/policy-exchange-launches-new-history-project/. Policy Exchange features an image of the Grade II listed equestrian statue of Richard Lionheart outside the Palace of Westminster with this text.
} 
cultural organisations in England a letter warning them against removing statues or other objects of contested cultural heritage from public display at the risk of losing their public funding. ${ }^{10}$ In October, in a speech delivered at the end of Black History Month, Kemi Badenoch, Minister for Equalities, asserted firmly that, in schools and universities, 'our curriculum does not need decolonising' and warned that any school uncritically teaching Critical Race Theory 'is breaking the law'. ${ }^{11}$ In November, Conservative life peer Baroness Eaton intervened, “To ask Her Majesty's Government what assessment they have made of steps taken by some universities to decolonise the history curriculum; and what plans they have to issue guidance to universities on making the history curriculum as previously taught available to students. ${ }^{12}$ That History not only matters but is also fundamentally different rings out from these debates. MPs and peers do not argue that the teaching of evolution in schools and universities must be balanced by Creationist pedagogy, nor (thank goodness) do they suggest that compulsory relationship teaching on LGBT+ equality in primary schools must be matched by compulsory lessons on how to be homophobic. When it comes to History, however, science - in the sense of Wissenschaft, or the systematic pursuit of new knowledge - not only flies out the window, but is held up to ridicule and opprobrium. In the common parlance of our times, it is 'cancelled'.

What are the defining features of the History that proponents of this dominant paradigm of culture war propound? The Policy Exchange 'History Matters' project provides useful evidence for answering this question. In June 2020, the group established a webpage to register examples of Britain's 'culture war' under four main rubrics: Statue Removals, Name

\footnotetext{
10 'Letter from Culture Secretary on HM Government position on contested heritage', 22 September 2020, https://www.gov.uk/government/publications/letter-from-culture-secretary-on-hm-government-position-oncontested-heritage (accessed 9 July 2021).

${ }^{11}$ Calvin Robinson, 'Kemi Badenoch is right to take on Critical Race Theory', Spectator, 21 October 2020: https://www.spectator.co.uk/article/kemi-badenoch-is-right-to-take-on-critical-race-theory.

12 'Decolonising the History Curriculum', written question tabled 8 October 2020, House of Lords, [HL8921]: https://lordsbusiness. parliament.uk/ItemOfBusiness?itemOfBusinessId=84702\&sectionId=50\&businessPaperDa te $=2020-10-09$.
} 
Changes, Apologies and "Decolonising" the Curriculum. Three further 'editions' had augmented this rolling 'compendium' of evidence by 24 September $2020 .{ }^{13}$ Adorned by images of government ministers, they add Art Symbols, Museums, Galleries and Institutions, Education, and Public Spaces to a roster that echoes lists of the war dead inscribed on memorial monuments. ${ }^{14}$ The presentation of these data is unsystematic, and Policy Exchange offers no information on any selection criteria for inclusion or exclusion they have applied. Nonetheless, several salient features emerge from the 99 entries. Material culture and the built environment feature prominently in History Matters' understanding of History's pedagogic duty. In their first four editions, 24 per cent of their entries mention the renaming of buildings, roads or schools, while 23 per cent mention public statues, busts or commemorative plaques. (In contrast, only 13 per cent reference the decolonisation of university curricula). ${ }^{15}$ The absence of women from this monumental vision of Britain's national history is a notable, but unremarked, characteristic of the 'History Matters' campaign: by default, the project's vision conceptualises history and heritage as inherently masculine domains. ${ }^{16}$ Public monuments controlled by local councils dominated the first edition, but the project's fourth edition turned attention increasingly to cultural and educational organisations, renewing its 'call for evidence asking museum directors, curators, teachers and the wider public to share their experiences and concerns about the ways in which history is being politicised, and sometimes distorted' ${ }^{17}$

\footnotetext{
13 The editions (3, 4 and 24 September 2020) are attributed to Alexander Gray, Research Fellow, Security and Extremism: https://policyexchange.org.uk/history-matters-project/page/4/ and https://policyexchange.org.uk/history-matters-project/page/3/ (accessed 9 July 2021). The subsequent editions are dated 20 October 2020-9 April 2021.

14 'History Matters', $1^{\text {st }}$ edition, 28 June 2020: https://policyexchange.org.uk/publication/history-matters-project/ (accessed 9 July 2021).

15 The unsystematic presentation of the Policy Exchange data renders precise analysis problematic.

16 The hyper-masculine understanding of the past projected by History Matters is reflected in the composition of its list of 'at risk' statues and busts. This includes Robert Baden-Powell, Lt Col. Benson, James Boulton, Sir John Cass, Joseph Chamberlain, Sir Robert Clive, Edward Colston, Viscount Combermere, Oliver Cromwell, Sir Robert Geffrye, Thomas Guy, Viscount Melville, Robert Milligan, Lord Nelson, Sir Robert Peel, Thomas Picton, General Sir Redvers Buller, Cecil Rhodes, Sir Hans Sloane and James Watt.

${ }^{17}$ https://policyexchange.org.uk/publication/history-matters-fourth-edition/ .
} 
The 'History Matters' group emphatically proclaims its own approach to the past to be free of politics. 'In cataloguing these examples, we do not offer any judgment on the actions of the individual or institution in question,' their website asserts. This claim sits uncomfortably with the group's conclusion - unchanged since it began to gather its evidence - that History today 'is the most active front in a new culture war, and that action is being taken widely and quickly in a way that does not reflect public opinion or growing concern over our treatment of the past.' ${ }^{18}$ These conflicting statements rest uneasily on the compendium's evidence, much of which lacks the conventional referencing that would allow the reader to test its veracity. ${ }^{19}$ Spot-checks of the patchy references and cited texts do not always inspire confidence. Item twelve of the $2^{\text {nd }}$ edition, for example, is headed by the bold claim that 'More than 180 historians have called on the Home Office to remove the history element of the UK citizenship test.' Navigating beyond 'History Matters' broken link to a mis-titled 'History Journal' that supposedly supports this claim, a persistent reader can view the offending letter in full via the Guardian website, as published in History: The Official Journal of the Historical Association. Here we learn that the 180 historians- of whom I am one- have not called for History to be removed from the Home Office test. Instead, they have requested that the factual errors with respect to the histories of slavery and empire (with which the current test is larded) be removed, rather than remaining compulsory learning for prospective UK citizens. ${ }^{20}$

\footnotetext{
${ }^{18}$ Text cited from the introductory statements of the first and fourth editions (accessed 9 July 2021). Policy Exchange's approach to factual evidence has, more broadly, attracted critical comment. See for example responses to a 2019 Policy Exchange report on the 'crisis' of free speech at universities which wrongly claimed that Germaine Greer had been no-platformed at Cardiff University, a claim subsequently reported in the House of Commons: Anna Fazackerley, 'Gavin Williamson using "misleading” research to justify campus free-speech law’, Guardian, 27 February 2021.

${ }^{19}$ For example, citations to newspaper articles that lack dates (a problem exacerbated when the articles are located behind paywalls), the presence of broken hyperlinks and the absence of names of authors cited.

${ }^{20}$ Item 12, second edition: https://policyexchange.org.uk/publication/history-matters-project-second-edition/; the letter, posted on History 21 July 2020, can be accessed from: https://historyjournal.org.uk/2020/07/21/historians-call-for-a-review-of-home-office-citizenship-and-settlementtest/.
} 
Based on a tendentious evidence base, the 'History Matters' project is at least as illuminating for what it leaves out as for what it takes into its purview. The place of the East India Company in Britain's imperial pantheon is one of these many salient silences. Like the 50-ish percent of the population that is female, over three centuries of British imperial expansion in South Asia are conspicuous for their absence from view. ${ }^{21}$ A passing reference to Lord Adonis's desire to topple the statue of Robert Clive and an (equally cursory) mention of a proposal by Ealing Council to rename Havelock Road as Guru Nanak Road, appear to represent the full extent of India's place in the British empire, until the celebrated life of Winston Churchill hoves into view. ${ }^{22}$

Where EIC men do feature in the project's pantheon, their exploits in India are unacknowledged. Item 4 of the first edition of its compendium of evidence of a raging culture war fuelled by cancel culture, for example, instances Chester Council's discussion of whether to remove a large equestrian statue of Viscount Combermere from the city centre. 'Field Marshal Stapleton Cotton, 1st Viscount Combermere was a military leader, diplomat and politician and made a Field Marshal in 1855,' the website observes. 'He served under the Duke of Wellington in the Peninsular War. ${ }^{, 23}$ Absent from this analysis is the rationale for the debate on Combermere's statue: he served as Governor of Barbados from 1817 to 1820 and was financially compensated for Parliament's emancipation of 420 enslaved persons on Nevis and St Kitts in $1834 .{ }^{24}$ Also missing from this description of Combermere's valour is his career in India. A veteran of the Fourth Anglo-Mysore War, Combermere first met Wellington not in Europe but in the Madras Presidency, where both men established their

\footnotetext{
${ }^{21}$ Queen Victoria and Elizabeth II are the only women (figured as statues/plaques rather than as persons) named in the 99 entries who are female. The 99 entries mention far more than 99 persons in total.

${ }^{22}$ Clive features in the First Edition (Item 9); Havelock in the Second Edition (Item 2); Churchill (in the context both of the Bengal Famine of 1943 and of his opposition to Indian independence) in the Second Edition (Item

26) and the Fourth Edition (Item 13).

${ }^{23}$ First Edition (Item 4).

${ }^{24}$ Legacies of British Slave-ownership database, Stapleton Cotton, $1^{\text {st }}$ Viscount Combermere:

https://www.ucl.ac.uk/lbs/person/view/25180 (viewed 14 November 2020).
} 
military repute. ${ }^{25}$ His full title reflects contemporary recognition of the central part that India played throughout his career. He was Viscount Combermere of Bhurtpore in the East Indies because - as Commander-in-Chief of India in the 1820s — he presided over the reduction of a Mahratta fort long held to be impregnable. ${ }^{26}$ Selective amnesia of the East India Company's place in the wider fabric of the British empire is by no means peculiar to the Policy Exchange's initiative. ${ }^{27}$ Rather, it characterises wider public rememberings and forgettings of empire in India in our so-called culture war.

\section{Empire Men, the East India Company \& the Country House}

Why does India in general and the East India Company in particular play such a limited role in present-day discussions of the British empire? Debates spurred by the Black Lives Matter movement unsurprisingly have focused attention on the slave systems of the Atlantic World, and the role played by slave-trading and slave-owning British men in upholding them. In turning attention to India, it is not my intention to efface those vitally important histories, but rather to locate them in a wider imperial system in which the Atlantic and Indian Ocean Worlds were both entwined and mutually sustaining. ${ }^{28}$ Combermere's biography_like his stately home in Cheshire_embodies this entanglement.

\footnotetext{
${ }^{25}$ H.M. Chichester, revised by James Lunt, 'Cotton Stapleton, first Viscount Combermere (1773-1865), Oxford Dictionary of National Biography (Oxford, 2004; 11 March 2021 edition).

${ }^{26}$ Memoirs and Correspondence of Field Marshal Viscount Combermere, from His Family Papers, ed. M.W.S. Cotton [Viscountess Combermere] and W. Knollys, 2 vols (1866), chaps 2-3.

${ }^{27}$ Subsequent to the delivery of this lecture, this point has been made especially forcibly by Sathnam Sanghera, Empireland: How Imperialism Has Shaped Modern Britain (2021), chap. 11, esp. 197.

${ }^{28}$ For the EIC's entanglement with Atlantic World Slavery, see Chris Jeppesen, 'East Meets West: Exploring the Connections between Britain, the Caribbean and the East India Company, c. 1757-1857', in Britain's
} 
A Cistercian foundation established in the $12^{\text {th }}$ century, Combermere Abbey passed into the Cotton family with the dissolution of the monasteries. Newly knighted by Henry VIII, Sir George Cotton gained the Abbey and its 22,000 acres in the 1540s, and promptly demolished its main buildings - a salutary reminder that processes of erasure have played an integral part in forging Britain's four nations for centuries. The resulting Tudor manor house was remodelled by successive generations, obtaining its current, Gothic style at the behest of the $1^{\text {st }}$ Viscount in the aftermath of the Napoleonic wars. ${ }^{29}$ Today the Abbey operates as a luxury wedding venue, 'Steeped in a thousand years of English history'. What does it mean to be steeped in English history? The 'History' tab of the Combermere Abbey website depicts the English past as an insular national history, shorn of references to colonial wealth and imperial military exploits. ${ }^{30}$ The highpoints of this potted history offer a sharp contrast to the evidence presented to the public by Combermere's family and friends in the Georgian and Victorian eras. Here we find instead a man propelled into empire by the profligate hospitality of his father, whose devotion to country pursuits had forced the sale of family estates valued at $£ 200,000$ (or, over $£ 8$ Million in today’s currency). ${ }^{31}$ Service as Governor in Barbados (1817-20), Commander-in-Chief of Ireland (1822-25) and Commander-in-Chief of India (1825-30) clearly reflected Combermere's staunch conservative values. 'Toryism has been for centuries an heirloom of the Cotton family, and he cherished it with careful fidelity', the Victorian biography orchestrated by Combermere's family asserted. 'The British officer, he thought, should be essentially conservative, as the guardian of established rule and the enemy to changes which might implicate the chivalrous loyalty to which he is sworn. ${ }^{32}$ But his

History and Memory of Transatlantic Slavery, ed. Katie Donington, Ryan Hanley and Jessica Moody (Liverpool, 2016), 116-140.

${ }^{29}$ Combermere Abbey Estate: https://combermereabbey.co.uk/history/. See also https://www.historichouses.org/houses/house-listing/combermere-abbey.html.

${ }^{30} \mathrm{https}$ ://combermereabbey.co.uk/history/. Highpoints include Henry VIII's dissolution of the monasteries, 'extensive Gothic remodelling' from 1775-1820, the estate's purchase by Sir Kenneth Crossley of Crossley Motors in 1919 and service as an evacuee girls' school in World War II.

${ }^{31} \mathrm{https}: / / \mathrm{www} . u c l . a c . u k / \mathrm{lbs} /$ person/view/25180.

32 Memoirs and Correspondence, 2: 376-77. 
imperial career was hardly an innovation. His family's political and economic fortunesincluding their purchase of English landed estates_-had, since the seventeenth century, been predicated on ownership of sugar plantations and the enslaved humans whose forced labour extracted profits from the four Leeward Islands. ${ }^{33}$

While serving as Governor of Barbados in the 1810s, Combermere refashioned the Abbey in Gothic style, installing a Wellington Wing to commemorate the senior officer with whom he had served both at the storming at Seringapatam in India in 1799 and later in the Peninsular War. Inside the Abbey, behind it new, mock-Gothic façade, the impress of India is readily discerned in material culture acquired by the commonplace practices of empire in South Asia: conquest, gifting, loot and prize. Combermere was an adept practitioner of the acquisitive collecting practices associated with East India Company military campaigns. ${ }^{34}$ Writing to the Governor General, Lord Amherst, during the reduction of Bharatpur Fort, he provided detailed military intelligence, interlaced with news of the items seized from the Raja's palace that he was sending as gifts to Amherst, his wife and his daughter. ${ }^{35}$ The treasure taken by his army was valued at $£ 480,000$ (in excess of $£ 27$ Million pounds today), of which $£ 500$ was expended to mount two brass field-pieces presented by the army to the Commander-in-Chief. '[T]hey now stand in a gallery [at Combermere Abbey] lined with armour and every description of weapon', Mary, Viscountess Combermere and Captain Knollys reported in their Memoirs \& Correspondence of Combermere in $1866 .{ }^{36}$ Elevated to

\footnotetext{
${ }^{33}$ This wealth, much augmented by intermarriage with women of the Caribbean planter aristocracy, is delineated by J.R.V. Johnson, 'The Stapleton Sugar Plantations in the Leeward Islands', Bulletin of the John Rylands Library, 48: 1 (1965), 175-206.

${ }^{34}$ These collecting practices are detailed in the first three lectures of this series: Margot Finn, 'Material Turns in British History: I: Loot', Transactions of the Royal Historical Society, 28 (2018), 5-32; idem., 'Material Turns in British History: II: Corruption: Imperial Power, Princely Power, Princely Politics and Gifts Gone Rogue', Transactions of the Royal Historical Society, 29 (2019), 1-25; and idem., 'Material Turns in British History: III: Collecting: Colonial Bombay, Basra, Baghdad and the Enlightenment Museum', Transactions of the Royal Historical Society, 30 (2020), 1-28.

${ }^{35}$ Combermere to Lord Amherst, 19 December 1825, 22 January 1826, 24 January 1826, British Library, MSS Eur F140/80 (a).

${ }^{36}$ Memoirs of Correspondence, 2: 126.
} 
Viscount for this victory, Combermere as Commander-in-Chief was entitled to one eighth of the Bharatpur prize money, a hefty sum worth just under $£ 3.5$ Million today. ${ }^{37}$

The months that followed this victory of 1826 saw Combermere travel throughout the Upper Provinces of Bengal, reviewing his troops, engaging in diplomacy with Indian princes and collecting artwork and armour for display at his English country house. Among the Indian princely states which the East India Company was, variously, using to shore up its power and seeking to supplant, the Viscount found many elite Indian advocates of a country house aesthetic compatible with his own. The newly installed King of Avadh, he reported to his sister, 'has, besides his many palaces, five or six country houses, quite English, with English furniture and pictures. ${ }^{, 38}$ Diplomatic encounters such as these entailed lavish celebrations in which Indian princes and the Commander-in-Chief exchanged elaborate, costly gifts. East India Company policy strictly prohibited the retention of these presents by British officers, ${ }^{39}$ but the printed memoirs published by Combermere's family and friends in the Victorian era clearly documented the flow of gifted Indian weaponry from these diplomatic encounters to Combermere Abbey. ${ }^{40}$ The Raja of Patiala, a connoisseur of both Indian and English material culture, gifted the Commander-in-Chief 'a complete suit of chain-armour...inlaid with gold, a sword and shield, a bow and arrows, and a dagger', the Viscount's Victorian biographers noted. 'These may now be seen in the armoury at Combermere, side by side with many other weapons obtained during his residence in India,' they observed. ${ }^{41}$ Policy Exchange's 'History Matters' project identifies historians who draw attention to English material culture's imbrication with empire figure as a 'woke' cavalry

\footnotetext{
${ }^{37}$ Ibid., 2: 127. See also 2: 215-216, 235-240.

38 Ibid., 2: 159.

${ }^{39}$ See Finn, 'Material Turns: III: Corruption'.

${ }^{40}$ Memoirs and Correspondence, 2: 171-172. See also 2: 151-52, 159. This gifting is a frequent theme in the memoir of Combermere's ADC, Major Archer, Tours in Upper India, and in the Parts of the Himalaya Mountains; With an Account of the Courts of the Native Princes, \&c. (2 volumes; 1833), for example 1: 7-10, $188-89$.

${ }^{41}$ Memoirs \& Correspondence, 2: 171-72.
} 
intent to distort national history by 'rewriting' it. Taking a longer view, however, of EIC material culture, it is the $20^{\text {th }}$ and $21^{\text {st }}$ centuries' erasure of these colonial connections that is most striking, rather than historians' more recent attention to them. Already in the nineteenth century, Viscount Combermere's family and friends—no woke snowflakes they-drew repeated attention to the material legacies that flowed to Cheshire from India during his imperial career. There is no need to fall prey to the error against which Policy Exchange warns us - that is, 'judging our past with today's values' ${ }^{42}$ - to acknowledge a fact selfevident to the Victorians. Empire and the violence upon which it was founded were bedrocks of the modern British nation-state, providing the men who governed it with wealth, status and power that took conspicuous physical form in their stately homes.

Combermere Abbey's hybrid East (and West) Indian material culture is hardly anomalous. In September 2020, the National Trust published a report which identified 93 properties in its care in England and Wales with links to colonialism, including 29 whose proprietors (like Combermere) received financial compensation for Parliament's abolition of slavery in $1834 .{ }^{43}$ Ruffling many feathers, this important report amplified research on a much wider population of stately homes already in the public domain. In 2014, for example, historian Stephanie Barczewski identified hundreds of landed estates and country houses acquired with imperial wealth from 1700 to 1930 . Of these, 229 were purchased or restored with East Indian fortunes between 1700 and 1850. The heyday of East India Company men's stately home acquisition extended from the 1760 s through the $1810 \mathrm{~s} .{ }^{44}$ Counties such as Angus, Berkshire, Hertfordshire and Perthshire featured especially prominently in this

\footnotetext{
42 'Policy Exchange launches new history project' (28 June 2020): https://policyexchange.org.uk/pressrelease/policy-exchange-launches-new-history-project/.

${ }^{43}$ Sally-Anne Huxtable, Corinne Fowler, Christo Kefalas and Emma Slocombe, eds, Interim Report on the Connections between Colonialism and Properties in the Care of the National Trust, Including Links with Historic Slavery (Swindon, 2020).

${ }^{44}$ Stephanie Barczewski, Country Houses and the British Empire, 1700-1930 (Manchester, 2014), esp. $52-53$.
} 
architectural feeding frenzy. But stately homes built with East India Company fortunes punctuated the landscape across the full range of British counties in these years. ${ }^{45}$

To be sure, not all Georgians and Victorians were as willing as Viscount Combermere to draw attention to the South Asian wellsprings of their country house lifestyles. In the stately homes of men from mercantile backgrounds who aspired to gentility and of members of the lesser gentry whose economic precarity threatened their status, a more self-conscious marriage between Indian wealth and material culture emerged. ${ }^{46}$ These men's architectural preferences, artistic tastes and furnishing choices point us to a pervasive strand of imperial amnesia mediated by their stately homes - structures that were both made possible by colonial lives and used to mask the traces of empire in the families they funded and maintained.

The desire to preserve, repurchase or acquire a country house as a family seat repeatedly recurs in the biographies of the leading men who drove East India Company policies both on the subcontinent and in Parliament. The Oxford Dictionary of National Biography entry for Robert Clive notes that, born into a venerable but impecunious gentry family, 'Clive experienced a...peripatetic childhood and...spent much time away from his parents' and their Shropshire country house. On his first return from the subcontinent in 1753, Clive unsurprisingly used his Indian fortune of $£ 40,000$ to pay his family’s debts, including the mortgage on the family seat. Together with the purchase of new landed estates, this country house base allowed him to enter Parliament and build an East India Company interest in the House of Commons. ${ }^{47}$ Likewise, Warren Hastings used the savings garnered

\footnotetext{
45 This phenomenon is detailed in Margot Finn and Kate Smith, eds, The East India Company at Home, 17571857 (2018), available open access from https://www.uclpress.co.uk/products/88277.

${ }^{46}$ For the negative stereotypes associated with EIC men of wealth and their landed estates, see J.M. Holzman, The Nabobs of England 1760-1815: A Study of the Returned Anglo-Indian (New York, 1926) and Tillman Nechtman, Nabobs: Empire and Identity in Eighteenth-Century Britain (Cambridge, 2010).

${ }^{47}$ H.V. Bowen, 'Clive, Robert, first Baron Clive of Plassey (1725-1774)', Oxford Dictionary of National Biography (Oxford, 2004; 3 January 2008 version).
} 
from his Indian career to recuperate the estate in Worcestershire, to which his family traced its history continuously from the $12^{\text {th }}$ century. Returning to England in 1785, Hastings 'immediately set about trying to realize the objective that he had long set himself, the recovery of the Daylesford estate for the Hastings family', P.J. Marshall observes in the Oxford Dictionary of National Biography. Commissioning a new family seat by Samuel Pepys Cockerell, Hastings spent $£ 60,000$ of his $£ 220,000$ Indian fortune on Daylesford and its pleasure grounds, which he occupied with his wife from 1791, living 'the life of a country gentleman, engaged in local affairs and farming. ${ }^{48}$

If we examine the external signifiers of East India Company men's country houses, processes of imperial erasure - Georgian era architectural 'cancel culture', if you will— become conspicuously evident. Samuel Pepys Cockerell's most famous 'English' country house is not his reconstruction of Warren Hastings's beloved Daylesford, but instead the nearby, new home he designed for his own elder brother Charles in 1805. Charles (later Sir Charles) Cockerell retired from the East India Company civil service as a wealthy 'nabob' in 1801. He was typical of a late Georgian generation of Company men enriched far beyond their mercantile origins and determined to translate their prodigious Indian wealth into social and political power at home through family seats set on landed estates and parliamentary seats at Westminster. ${ }^{49}$ The entrance of these men into the House of Commons stoked fears of an 'Oriental' overthrow of British liberties; Cockerell indeed first sat for a notoriously corrupt Cornwall constituency that was in the gift of his 'fellow nabob', Richard Barwell. ${ }^{50}$ But his country seat, fashioned in a pastiche of Indian architectural styles now termed neo-

\footnotetext{
${ }^{48}$ P.J. Marshall, 'Hastings, Warren (1732-1818)', Oxford Dictionary of National Biography (Oxford, 2004; 4 October 2008 version).

${ }^{49}$ J.W. Anderson and R.G. Thorne, 'Cockerell, Charles (1755-1837), of Sezincote, Glos.', in The History of Parliament: the House of Commons 1790-1820, ed. R. Thorne (Cambridge, 1986): https://www.historyofparliamentonline.org/volume/1790-1820/member/cockerell-charles-1755-1837. ${ }^{50}$ Philip Lawson and Jim Phillips, "'Our execrable banditti": Perceptions of Nabobs in Mid-eighteenth Century Britain', Albion, 16: 3 (1984) 225-41; Anderson and Thorne, 'Cockerell'.
} 
Mughal or Indo-Saracenic, is entirely atypical of East India Company country houses.

Sezincote House reputedly inspired the Prince of Wales's construction of the Royal Pavilion at Brighton, but it failed to capture the imagination of East India Company men. ${ }^{51}$ Their characteristic architectural aesthetic spanned from the monastic abbey to mock Gothic structures, but was firmly centred in Palladianism and its neo-classical offshoots. These dominant styles rejected Indian influences, adopting instead 'the forms and ornament of ancient Roman buildings to create an architecture based on symmetry, proportion and perspective. ${ }^{52}$ Sir Francis Sykes's new country house at Basildon Park in Berkshire and Sir Thomas Rumbold's new house at Woodhall Park in Hertfordshire exemplify this trend. ${ }^{53}$ In Wales, William Paxton's neo-classical new-build, Middleton Hall, likewise emphatically announced that this erstwhile East India Company surgeon had arrived in the gentry. ${ }^{54}$ North of the Border, Novar House no less triumphantly signalled the return of Sir Hector Munro to his ancestral lands with the spoils of Indian warfare, which allowed him dramatically to expand his family home, reconfiguring its footprint as a classical square. ${ }^{55}$

'Nabob' was a term of abuse in Georgian Britain. A Persian word that designated a provincial governor in the Mughal empire, 'nawab' was transmogrified into nabob by vociferous British critics of the East India Company's nascent empire in the aftermath of Clive's victory at Plassey. To contemporaries, nabobism signified all that was wrong with

\footnotetext{
${ }^{51}$ Christopher Edward Clive Hussey, 'Sezincote, Gloucestershire', Country Life, 85 (1939) 502-6, 528-32; Jan Sibthorpe and Ellen Filor, 'Outside the Public: The Histories of Sezincote and Prestonfield in Private Hands', in New Paths to Public Histories, eds Margot Finn and Kate Smith (Basingstoke, 2015), 100-135.

52 'Palladianism': https://www.vam.ac.uk/collections/palladianism .

${ }^{53}$ See the National Trust's 'History of Basildon Park': https://www.nationaltrust.org.uk/basildonpark/features/history-of-basildon-park and Historic Houses' 'Woodhall Park': https://www.historichouses.org/house/woodhall-park/visit/ .

${ }^{54}$ W.G.J. Kuiters, 'Paxton, Sir William (1743/3-1824)', Oxford Dictionary of National Biography (Oxford, 2004); Lowri Ann Rees, 'Welsh Sojourners in India: The East India Company, Networks and Patronage, c. 1760-1840', Journal of Imperial and Commonwealth History, 45:2 (2017), 167. Significantly, Paxton's neo-classical Middleton Hall was designed for him by Samuel Pepys Cockerell.

${ }^{55}$ Andrew Mackillop, 'The Highlands and the Returning Nabob: Sir Hector Munro of Novar, 1760-1807', in Emigrant Homecomings: The Return Movement of Emigrants, 1600-2000, ed. Marjory Harper (Manchester, 2005), 233-61.
} 
East India Company rule: famine and exploitation on the subcontinent, followed by an inflow of excessive new wealth and political corruption to Britain - both signified by the purchase and extravagant refashioning of rural stately homes. ${ }^{56}$ 'Here is a specimen of the new... aristocracy created...against the natural interests of this kingdom', Edmund Burke declaimed in the House of Commons in 1785, excoriating the nabob Paul Benfield.

'A...criminal, who long since ought to have fattened the region [sic] kites with his offal, is...enfeoffed with an estate, which... effaces the splendor [sic] of all the nobility of Europe', Burke raged. ${ }^{57}$ James Gillray's 1797 caricature of Benfield, riding in front of his Palladian country house in Hertfordshire, registered the perceived dangers to the polity of this Asian wealth by racializing Benfield as 'black'. 58

In this fraught political context, not least among the virtues of neo-classical and neoGothic country house facades was their role in downplaying the South Asian origins of Company men's wealth and power. Inside stately homes, Georgian and early Victorian propertied elites navigated uneasily between the celebration, the domestication and the denial of the Indian taproots of their British fortunes. Armorial porcelain crafted in Jingdezhen and elaborate Chinese wallpaper were luxury furnishings to which families with East India Company connections enjoyed disproportionate access. ${ }^{59}$ Highly prized by members of the Georgian governing elite, today they are carefully preserved in the collections of the National Trust, providing a visual record of patterns of imperialism whose virtues have been hotly contested in Britain since the eighteenth century. ${ }^{60}$ Women participated avidly in the imperial collecting practices that shaped this material culture. In South India, while her husband, the

\footnotetext{
${ }^{56}$ Nechtman, Nabobs, offers the most comprehensive analysis of this phenomenon.

${ }^{57}$ Edmund Burke, 'Speech on the Nabob of Arcot's Debts', in The Writings and Speeches of Edmund Burke. Volume V India: Madras and Bengal 1774-1785, ed. P.J. Marshall (Oxford, 1981), 544-545.

${ }^{58}$ See James Gillray, 'Count Rupee', published by Hannah Humphrey 5 June 1797, National Portrait Gallery: NPG D12616 : https://www.npg.org.uk/collections/search/person/mp61740/paul-benfield .

${ }^{59}$ Finn and Smith, eds, The East India Company at Home.

${ }^{60}$ Huxtable, Fowler, Kefalas and Slocombe, Interim Report.
} 
Governor of Madras Presidency, worked to install a new, Hindu princely government after the defeat of Tipu Sultan in 1799, Lady Henrietta Clive, travelled extensively throughout Mysore. Accompanied by her teenage daughters, she collected loot, booty and luxury merchandise for Powis Castle, the family seat in Wales. Here the ornate chintz tent that had earlier accompanied Tipu Sultan on travels to survey his domains offered an arresting visual reminder of his defeat, when put to domestic use at Lady Clive's elite garden parties. ${ }^{61}$

In Georgian portraiture, we find intriguing material traces of the black lives that mattered to the elite status of this imperial ruling class. ${ }^{62}$ Many South Asian domestic workers accompanied East India Company families from the subcontinent to stately homes in Britain, both as servants and as enslaved domestic staff. ${ }^{63}$ Sir Hector Munro returned home to Scotland from his Indian campaigns with an entourage that included 'a BLACK SLAVE, a native of the East Indies, called CÆSAR' who, having absconded from his master's country house in 1771 , was advertised for in the Caledonian Mercury. ${ }^{64}$ In the early nineteenth century, having retired to Berkshire from Bengal, William Hickey was attended by — and painted with - his Indian man servant, William Munnoo. Their joint portrait, exhibited at the Royal Academy in 1820, designated William Munnoo as 'black', reminding us of the extended timeline and complex composition of black British histories. ${ }^{65}$ Hickey's social circle in Bengal had included the family of Sir Henry Russell. In England, he resumed his

\footnotetext{
${ }^{61}$ Nancy K. Shields, ed., Birds of Passage: Henrietta Clive's Travels in South India 1798-1801 (2009).

${ }^{62}$ See for example the portrait of Sir Hector Munro and his Indian manservant, attributed to David Martin and painted in 1785 after Munro's return to Scotland from the subcontinent: National Portrait Gallery, London, NPG 1433: https://www.npg.org.uk/collections/search/portrait/mw04577/Sir-Hector-Munro .

${ }^{63}$ Satyasikha Chakraborty, ""Nurses of Our Ocean Highways": The Precarious Metropolitan Lives of Colonial South Asian Ayahs', Journal of Women's History, 32: 2 (2020), 37-64; Michael Fisher, 'Bound for Britain: Changing Conditions of Servitude, 1600-1857', in Slavery \& South Asian History, ed. Indrani Chatterjee and Richard Eaton (Bloomington, IN, 2006), 187-209.

${ }^{64}$ Caledonian Mercury, 22 June 1771. Further examples of Indian (as well as African and Caribbean) enslaved runaways in Britain can be identified from the Runaway Slaves in Britain: Bondage, Freedom and Race in the Eighteenth Century database: https://www.runaways.gla.ac.uk/ .

${ }^{65}$ See the 1819 portrait by William Thomas of William Hickey of the EIC civil service, depicted at home in England with his Indian manservant, William Munnew (or Munnoo), National Portrait Gallery, London, NPG 3249: https://www.npg.org.uk/collections/search/portrait/mw03129/William-Munnew-or-Munnoo-WilliamHickey . For William Munnew's legal status, see Fisher, ‘Bound for Britain', 203-205.
} 
friendship with Lady Russell, who had returned home with her youngest, Indian-born children and two Indian servants while her husband and eldest sons remained in India, accumulating the capital with which, in 1820 , they would purchase a stately home. ${ }^{66}$ As Lady Russell tested country house life in Surrey, Kent and Somerset, she was accompanied and supported by Indian attendants. "I have found both my Black Women faithful good Souls....As to Anne Ayah she has really so attached herself to me that I think I never can part with her,' Lady Russell wrote in 1805. “'Anne Ayah (who is now call'd Mrs Williams, being my Maid) I cannot part with, she is in many respects superior to an English Servant, and in no one inferior - her attachment to me is quite wonderful,' she enthused a year later. ${ }^{67}$

\section{The Selective, Collective Amnesias of Imperial Imagination.}

The Berkshire country house Lady Russell's husband and eldest son acquired in 1820,

Swallowfield Park, embodies in its history, fabric and furnishings many of the contradictions, silences and erasures that marked (and masked) East India Company material culture. Its exterior gives no sign of Swallowfield's extended connection with empire in the East and West Indies. ${ }^{68}$ But the Russells' extensive family archive sheds light on its many vestiges of empire — some obscured, but others displayed in plain view. Henry Russell, whose father Sir Henry Russell had served as Chief Justice in Bengal, amassed a substantial collection of

\footnotetext{
${ }^{66}$ Margot Finn, 'Swallowfield Park, Berkshire: From Royalist Bastion to Empire Home', in Finn and Smith (eds), East India Company at Home, 205-230, 461-66.

${ }^{67}$ Lady Russell to Charles Russell, 12 March 1805 and 30 March 1806, Bodleian Library, MS Eng. Lett. c. 154, fols 66 verso and 101.

${ }^{68}$ Lady Constance Russell, Swallowfield and Its Owners (1901) provides both images of the house and perspectives on its history from the Tudors through the Victorian era.
} 
Indian art while serving as the Company's diplomatic representative at Hyderabad. ${ }^{69}$ At Swallowfield, this artwork, a portrait of Russell by Romney and copies of paintings by Old Masters he acquired with his Indian savings, together adorned the walls. Keen to consolidate and burnish his family's lineage, the second baronet carefully constructed a gallery of family portraits, commissioning the society artist David Wilkie to retouch a painting of his paternal grandmother, to make her more genteel. ${ }^{70}$

Excluded from Swallowfield's family gallery, however, was Henry's mixed-race daughter, Mary Wilson — one of three children born to him and his several Indian concubines. Sent 'home' to Britain on a separate ship to her father, his wife and their legitimate, white children, Mary was established at a boarding school in Clapham and trained up be a governess, under the guardianship of Major Pitman, a retired East India Company military officer who had served at Hyderabad with her father. Despatched as an adolescent to service in a Devonshire country house, Mary Wilson repeatedly begged her guardian to know whose child she was. Her father was adamant both that his identity be kept from her, and that she should not step foot in his Berkshire country house. ${ }^{71}$ Material legacies of empire were clearly one thing to display, human legacies quite another.

There is no need anachronistically to apply twenty-first century sensibilities to censure Henry Russell's treatment of his mixed-heritage daughter. Her guardian, Major Pitman, as well as Henry's brothers and in-laws were both bemused and infuriated by his intransigence on this score. '[T]he dear childs [sic] mind for some time back has been much agitated on the subject of her birth, of which I have avoided giving her any explanation', Major Pitman wrote to Sir Henry in 1838. 'At her age it is natural she should think deeply on

\footnotetext{
${ }^{69}$ Examples include a watercolour of the emperor Akbar watching an elephant fight, painted c. 1780 and purchased by Russell in Hyderabad c. 1800-20, now in the National Gallery of Australia, Accession No. 91.1409: https://searchthecollection.nga.gov.au/object?uniqueId=157166 .

${ }^{70}$ Finn, 'Swallowfield Park', 223-24.

${ }^{71}$ Ibid., 229-30.
} 
a subject so interesting to her and I hope.....you will agree with me in...setting her mind at rest regarding it,' he pleaded. ${ }^{72}$ Russell's brothers, his wife's sister and his brother-in-law all happily met and acknowledged Mary Wilson, commenting openly on her physical resemblance to her father. But Russell, citing the interests of his wife and legitimate, white daughters to justify his reasoning, repeatedly refused to declare his paternity. 'For the present I am satisfied...that we cannot tell Mary, whose daughter she is', he wrote to Pitman in 1839. 'In the first place, I could not tell her who she is, without at the same time receiving her at least occasionally into my house, and I find, what is perhaps not only natural but proper, that Lady R. would object to this, at all counts while her own daughters are unmarried. ${ }^{, 73}$

Tracking the Indian capital inherited by Henry Russell's sisters-Mary Wilson's aunts - also leads us to English country houses. Like Swallowfield, at first glance, the stately homes they inhabited in Lancashire and Devon appear to be quintessentially English. The drawing room of Henrietta Greene née Russell's country house was filled with fine furniture crafted locally by Gillows of Lancaster. ${ }^{74}$ But the house itself, Whittington Hall, was a new build financed in no small part with capital from Henrietta's dowry, funded by savings from her father's salary as a judge on the Calcutta Supreme Court. ${ }^{75}$ The neo-classical exterior of Winslade Park, the country house in Devon in which Henry's sister Rose resided, likewise simultaneously reflected and concealed imperial fortunes. Constructed earlier in the century for the nabob Edward Cotsford, Winslade had been purchased by Rose Porter née Russell's

\footnotetext{
${ }^{72}$ Major Pitman to Sir Henry Russell, $2^{\text {nd }}$ Bt, 14 April 1838, Bodleian Library, MS Eng. Lett. c. 170, fol. 26.

${ }^{73}$ Sir Henry Russell to Major Pitman, 9 October 1839, Bodleian Library, MS Eng. Lett. c. 170, fol. 51.

${ }^{74}$ Richard T. Lonsdale's painting of the interior of 'The Drawing Room at Whittington Hall, Lancashire', commissioned c. 1836 by Henrietta's husband, the M.P. Thomas Greene, depicts a cosy, English domestic interior 'splendidly furnished by the well-known cabinet-making firm of Gillows of Lancaster', as the Art Fund's notes observe: https://www.artfund.org/supporting-museums/art-weve-helped-buy/artwork/7086/thedrawing-room-at-whittington-hall-lancashire. Conventionally viewed as quintessentially 'English', Gillows' business enterprise was, in fact, closely imbricated with Caribbean slavery from the 1770s onward. See K.E. Ingram, 'The West Indian Trade of an English Furniture Firm', Jamaican Historical Review, 3: 3 (1962), 22-37. ${ }^{75}$ For Thomas Greene, see Margaret Escott, 'Greene, Thomas (1794-1872), of Slyne and Whittington Hall, Lancs', in The History of Parliament: The House of Commons 1820-1832, ed. D.R. Fisher (Cambridge, 2009): https://www.historyofparliamentonline.org/volume/1820-1832/member/greene-thomas-1794-1872.
} 
father-in-law, who was the proprietor of substantial estates in British Guiana. Rose's dowry provided an injection of Indian capital into the Porter finances when she married into the family in 1820. Abolition in 1834 brought the couple a second financial windfall. As the proprietor of 709 enslaved humans, Porter received $£ 35,960$ in compensation from Parliament, just under $£ 2.5$ Million in today’s money. ${ }^{76}$

At multiple levels and across the generations, country house material culture played vital roles in effacing the imperial past from contemporaries' memory. This selective amnesia was neither a passive nor an innocent process. We can trace its lineaments alike in stately home construction, in the decorative arts that defined a new Georgian country house aesthetic and in Victorian family history-writing. The biography of a silver-gilt presentation vase at Swallowfield brings this process of imperial erasure into clear view. In 1901, Swallowfield's then chatelaine, Lady Constance Russell, published a biography of her marital home, rooting its place in history firmly in the Tudor era and underlining its historic ties to the British monarchy. ${ }^{77}$ A commemorative vase dating from 1823 was one of the very few Russell family ties to India she chose to acknowledge. Funded by a subscription of over a thousand pounds presented to Henry Russell on his departure from Hyderabad in 1820, this decorative object—Lady Russell proudly proclaimed—was a small token of his colleagues' appreciation for Russell's imperial service. The records in the East India Company archive tell a very different story. In 1818, two years before his precipitate departure from Hyderabad, Russell had taken the law into his own hands, stepping beyond his diplomatic authority to order the flogging of two Indian men implicated in a robbery in the city's bazar. He subjected each man to 1,000 lashes, a punishment administered by his brother-in-law. Within two days, both

\footnotetext{
${ }^{76}$ Legacies of British Slave-ownership database: https://www.ucl.ac.uk/lbs/person/view/8022. See also https://historicengland.org.uk/listing/the-list/list-entry/1097566.

${ }^{77}$ Russell, Swallowfield.
} 
prisoners were dead. ${ }^{78}$ The Company's military officers at Hyderabad swiftly mobilised in defence of this brutal flogging, but the Governor General and Council in Calcutta were outraged at Russell's actions, and he resigned his post before he could be sacked. The vase, a ‘Tribute of Grateful Remembrance' funded by his subordinates at Hyderabad, was commissioned in the aftermath of this disgrace and proudly displayed at Swallowfield. ${ }^{79}$ Unsurprisingly, when it was auctioned in Salisbury in 2010, it was Lady Russell's patriotic version of its provenance, not the archival record of its contested heritage, that the auctioneers cited in their catalogue. ${ }^{80}$

\section{Conclusions.}

Today contested heritage figures prominently in a so-called culture war that rages across parliamentary politics, heritage organisations, educational institutions and social media. The Secretary of State for Culture has warned ostensibly arm's-length heritage organisations that they risk their funding if they 'politicise' history, while the Minister for Equalities has charged any school teacher who uncritically deploys Critical Race Theory with 'breaking the law' ${ }^{81}$ On Twitter and in the pages of the Daily Mail, the Telegraph and The Times, these sentiments have found a warm reception, as indignant readers have declaimed against 'cancel

\footnotetext{
${ }^{78}$ Finn, 'Swallowfield Park', 226-28.

${ }^{79}$ Ibid.

${ }^{80}$ Accompanied by an extensive quotation from Lady Russell's book to secure its provenance, the vase was estimated at $£ 20,000-30,000$ by Wooley \& Wallis and purchased by London dealers Koopman Rare Art for $£ 95,000$ : https://www.antiquestradegazette.com/news/2010/london-dealers-bid-95-000-for-rundell-vase-insalisbury/.

${ }^{81}$ Above, footnotes 10 and 11.
} 
culture' even as they have ostentatiously withdrawn their support from charities such as the National Trust by destroying their membership cards and cancelling their subscriptions. ${ }^{82}$

In this lecture, I have used the entwined material histories of the East India Company and the British country house to question two fundamental premises of our twenty-firstcentury culture wars. First, my reading of the imperial histories of stately homes since the eighteenth century challenges the claim — made by projects such as Policy Exchange's 'History Matters' - that present-day critiques of Britain's imperial past represent a novel, present-minded, 'woke' challenge to Britons' shared conception of the nation and its history. Rather, by pointing to Georgian-era diatribes against East India Company 'nabobs', I have suggested that such critiques were fundamental to many eighteenth- and nineteenth-century men and women's understanding of their own times. In the fabric, the artwork and the decorative cultures of the country houses they inhabited, we can trace a much earlier, highly politicised genealogy of heritage contests which continues to animate public understanding of the past today. By the Victorian era, Palladian and neo-Gothic architecture had definitively triumphed over the neo-Mughal, Indo-Saracenic style championed by Samuel Pepys Cockerell. By attending to the longer histories of British attitudes to empire, we can begin to understand why. For, the frequent assertion that critiques of imperialism today anachronistically subject past generations to twenty-first-century belief systems itself effaces from the historical record men, women and children who challenged slavery, racial bias and imperial conquest decades (and indeed centuries) ago. Their histories too can be found in the archives and in the artistic legacies of the country house, if we choose to seek them, rather than complacently, unthinkingly asserting that our moral values today invariably trump those of the generations that preceded us.

\footnotetext{
${ }^{82}$ Dominic Sandbrook's 'How dare the National Trust link Wordsworth to slavery because his brother sailed a ship to China', Daily Mail, 23 September 2020, exemplifies the dominant tone and substance of this critique.
} 
Second, my interpretation questions the commonplace claim that by re-writing familiar narratives of national icons such as country houses, historians fundamentally distort the settled verities of a stable past. Instead, I have suggested that re-writing history was an essential function of the country house, and that Georgian and Victorian families residing in stately homes were fully alive to this political purpose. The selective acquisition of desirable imperial luxuries, the selective exclusion of mixed-race progeny and the selective rewriting of family members' records of colonial service are all conspicuous in the amnesiac archives of Britons' stately homes. ${ }^{83}$ Nor is recognition of the integral role of selective remembering and forgetting in shaping nations a modish, politically-correct development of our century. Rather, it has been an axiom of historical analysis since at least the Victorian period. Ernest Renan-who was a close friend and intellectual companion of Sir Mountstuart Grant Duff, the fourth president of the Royal Historical Society, a former Governor of Madras, and no woke snowflake - articulated this argument forcefully in Qu'est-ce qu'une nation? (What is a Nation), published in 1882:

Forgetting, I would even say historical error, is an essential factor in the creation of a nation and it is for this reason that the progress of historical studies often poses a threat to nationality. Historical inquiry, in effect, throws light on the violent acts that have taken place at the origin of every political formation, even those that have been the most benevolent in their consequences. Unity is always brutally established. ${ }^{84}$

\footnotetext{
${ }^{83}$ Finn, 'Swallowfield Park'. For broader discussions of these processes of erasure, see for example Catherine Hall, Keith McClelland, Nick Draper, Kate Donington and Rachel Lang, Legacies of British Slave-ownership: Colonial Slavery and the Formation of Victorian Britain (Cambridge, 2014), chap. 5 and Katie Donington, The Bonds of Family: Slavery, Commerce and Culture in the British Atlantic World (Manchester, 2019).

${ }^{84}$ Ernest Renan, Qu'est-ce qu'une nation?, trans. Ethan Rundell as What Is a Nation? (Paris, 1992), 3. For Grant Duff and Renan, see Sir Mountstuart E. Grant Duff, Ernest Renan: In Memoriam (1893). Grant Duff's 'liberal' vision of history is discussed in the first lecture in this series, Finn, 'Material Turns I: Loot', 28-31.
} 
Bitterly contested at the time of its rapid territorial expansion in the aftermath of Clive's victory at Plassey, the East India Company played an instrumental role in forging the modern British state. Beyond passing mentions of Clive's statue at Whitehall, however, references to Britain's extended imperial history in South Asia are thin on the ground in the culture wars of the twenty-first century. This absence speaks eloquently to the ease with which we all fall prey to historical amnesia, and to the success with which earlier generations campaigned in and through their stately homes to encourage us to do so.

It is not the historian's role to serve as the handmaiden of public opinion by amplifying that pervasive, carefully constructed, selective view of the past - a view that is itself merely the most recent iteration of a long succession of interested forgettings and rememberings. Rather, rewriting history is precisely what historians do; it is how history works. There is no need to enter the lists of a novel culture war to rewrite the history of Britain's imperial past. That pathway is already well-trodden, thanks to our Georgian and Victorian forebears. 